\title{
Molecular mechanisms of leptin action in adult rat testis: potential targets for leptin-induced inhibition of steroidogenesis and pattern of leptin receptor messenger ribonucleic acid expression
}

\author{
M Tena-Sempere, P R Manna², F-P Zhang², L Pinilla, \\ L C González, C Diéguez ${ }^{1}$, I Huhtaniemi ${ }^{2}$ and E Aguilar \\ Department of Physiology, University of Córdoba, 14004 Córdoba, Spain \\ ${ }^{1}$ Department of Physiology, University of Santiago de Compostela, 15705 Santiago de Compostela, Spain \\ ${ }^{2}$ Department of Physiology, University of Turku, 20520 Turku, Finland \\ (Requests for offprints should be addressed to M Tena-Sempere, Department of Physiology, Faculty of Medicine, University of Córdoba, \\ Avda Menéndez Pidal s/n, 14004 Córdoba, Spain; Email: filtesem@lucano.uco.es)
}

\begin{abstract}
Leptin, the product of the $o b$ gene, is a pivotal signal in the regulation of neuroendocrine function and fertility. Although much of the action of leptin in the control of the reproductive axis is exerted at the hypothalamic level, some direct effects of leptin on male and female gonads have also been reported. Indeed, recent evidence demonstrated that leptin is able to inhibit testosterone secretion at the testicular level. However, the molecular mechanisms behind this effect remain unclear. The focus of this study was twofold: (1) to identify potential targets for leptininduced inhibition of steroidogenesis, and (2) to characterize in detail the pattern of expression and cellular distribution of leptin receptor (Ob-R) mRNA in adult rat testis. In pursuit of the first goal, slices of testicular tissue from adult rats were incubated with increasing concentrations of recombinant leptin $\left(10^{-9}-10^{-7} \mathrm{M}\right)$ in the presence of human chorionic gonadotropin (hCG; 10 $\mathrm{IU} / \mathrm{ml}$ ). In this setting, testosterone secretion in vitro was monitored, and expression levels of mRNAs encoding steroidogenic factor 1 (SF-1), steroidogenic acute regulatory protein (StAR), cytochrome P450 cholesterol sidechain cleavage enzyme (P450 scc) and $17 \beta$-hydroxysteroid dehydrogenase type III (17 $\beta-H S D)$ were assessed by Northern hybridization. In pursuit of the second goal, the pattern of cellular expression of the Ob-R gene in adult rat testis was evaluated by in situ hybridization using a riboprobe complementary to all Ob-R isoforms. In
\end{abstract}

addition, testicular expression levels of the different $\mathrm{Ob}-\mathrm{R}$ isoforms, previously identified in the hypothalamus, were analyzed by means of semi-quantitative RT-PCR. In keeping with our previous data, recombinant leptin significantly inhibited hCG-stimulated testosterone secretion. In this context, leptin, in a dose-dependent manner, was able to co-ordinately decrease the hCG-stimulated expression levels of SF-1, StAR and P450 scc mRNAs, but it did not affect those of $17 \beta-$ HSD type III. In situ hybridization analysis showed a scattered pattern of cellular expression of the $\mathrm{Ob}-\mathrm{R}$ gene within the adult rat testis, including Leydig and Sertoli cells. In addition, assessment of the pattern of expression of Ob-R subtypes revealed that the long $\mathrm{Ob}-\mathrm{Rb}$ isoform was abundantly expressed in adult rat testis. However, variable levels of expression of $\mathrm{Ob}-\mathrm{Ra}, \mathrm{Ob}-\mathrm{Re}$, and $\mathrm{Ob}-\mathrm{R} f \mathrm{mRNAs}$ were also detected, whereas those of the $\mathrm{Ob}-\mathrm{Rc}$ variant were nearly negligible. In conclusion, our results indicate that decreased expression of mRNAs encoding several up-stream elements in the steroidogenic pathway may contribute, at least partially, to leptin-induced inhibition of testicular steroidogenesis. In addition, our data on the pattern of testicular expression of $\mathrm{Ob}-\mathrm{R}$ isoforms and cellular distribution of Ob-R mRNA may help to further elucidate the molecular mechanisms of leptin action in rat testis.

Journal of Endocrinology (2001) 170, 413-423

\section{Introduction}

The obese $(o b)$ gene product, leptin, is an adipocytesecreted plasma hormone that plays a key role in the regulation of food intake, energy expenditure and body weight homeostasis (Friedman \& Halaas 1998). In addition, leptin has recently emerged as a pivotal metabolic signal in the regulation of reproductive function (Barash et al. 1996, Friedman \& Halaas 1998, Rosenbaum \& Liebel 1998, Casanueva \& Dieguez 1999). The absence of biological actions of leptin, due to mutations in the ob gene ( $o b / o b$ mice) or leptin receptor gene ( $d b / d b$ mice), leads to infertility whereas leptin administration advances the onset of puberty, maintains reproductive cyclicity despite acute 
fasting, and prevents sterility in $o b / o b$ mice (Ahima et al. 1996, 1997, Chehab et al. 1997, Mounzih et al. 1997). In addition, a stimulatory role of leptin in the control of luteinizing hormone (LH) and follicle-stimulating hormone (FSH) secretion has been documented (Barash et al. 1996, Nagatani et al. 1998). Compelling evidence indicates that the hypothalamus is the primary target for most of the action of leptin on the reproductive axis (Schwartz et al. 1996). However, based on the characterization of leptin receptor distribution and leptin effects on in vitro systems, additional sites for leptin action have been suggested, including the pituitary, testis and ovary (Zamorano et al. 1997, Spicer \& Francisco 1997, Caprio et al. 1999, Tena-Sempere et al. 1999a, Jin et al. 2000). Interestingly, evaluation of the direct testicular effects of leptin revealed its ability to inhibit testosterone secretion (Caprio et al. 1999, Tena-Sempere et al. 1999a, 2000a), a response analogous to that observed in terms of ovarian steroidogenesis after leptin stimulation in vitro (Spicer \& Francisco 1997, Zachow et al. 1999). Thus, it is tempting to propose a complex mode of action of leptin at multiple sites of the hypothalamic-pituitary-gonadal axis that involves both stimulatory and inhibitory responses.

The biological actions of leptin are carried out through interaction with its specific surface receptor. The leptin receptor (Ob-R) belongs to the cytokine receptor superfamily, containing a single membrane-spanning domain (Tartaglia 1997). Worthy to note, expression of the Ob-R gene results in an array of alternatively spliced isoforms (Ob-Ra to $\mathrm{Ob}-\mathrm{Rf})$, that share the extracellular domain but differ in the transmembrane/cytoplasmic regions (Tartaglia et al. 1995, Tartaglia 1997, Lee et al. 1996, Takaya et al. 1996). Among them, the Ob-Rb variant, with the longest cytoplasmic domain, appears as the functional, signal-transducing isoform in the hypothalamus (Tartaglia 1997, Casanueva \& Dieguez 1999). The functional role of the shorter $\mathrm{Ob}-\mathrm{R}$ subtypes remains to be fully elucidated. However, the ability of the Ob-Ra isoform to perform signal transduction has been reported (Murakami et al. 1997), and this variant has been shown to be involved in leptin transport across the blood-brain barrier (Tartaglia 1997, Bjorbæk et al. 1998). In addition, a role for the Ob-Re isoform as a soluble leptin-binding protein has been proposed (Tartaglia 1997). Moreover, modulation of $\mathrm{Ob}-\mathrm{Rb}$ function by co-expression of shorter $\mathrm{Ob}-\mathrm{R}$ isoforms has been reported (White et al. 1997, White \& Tartaglia 1999). In this scenario, it is likely that regulation of leptin action upon target tissues could depend, at least partially, on the balance of expression of the different $\mathrm{Ob}-\mathrm{R}$ isoforms.

The aim of the present study was to further explore the molecular mechanisms of leptin action upon adult rat testis. For this purpose, two experimental approaches were undertaken. First, we evaluated the ability of leptin to modulate mRNA expression levels of several key elements in the testicular steroidogenic pathway. Second, we assessed the pattern of testicular Ob-R gene expression. To this end, cellular distribution of Ob-R mRNA within adult rat testis was studied by means of in situ hybridization, and semi-quantitative RT-PCR was used to evaluate relative expression levels of mRNAs encoding different $\mathrm{Ob}-\mathrm{R}$ isoforms.

\section{Materials and Methods}

\section{Animals and drugs}

Adult (75-day-old) male Wistar rats were purchased from Charles River (Criffa, Barcelona, Spain). On arrival, the animals were housed under constant conditions of light $(14 \mathrm{~h}$ of light; lights on at $0700 \mathrm{~h})$ and temperature $\left(22{ }^{\circ} \mathrm{C}\right)$, with free access to standard laboratory animal food and tap water. All experimental procedures were approved by the Córdoba University Ethical Committee for Animal Experimentation and were conducted in accordance with the European Union standards for care and use of experimental animals.

Human recombinant leptin was produced in Sacharomyces cervisae as described elsewhere (Considine et al. 1996), and kindly donated by Eli Lilly (Indianapolis, IN, USA). Highly purified human chorionic gonadotropin (hCG; Profasi HP500) was purchased from Serono (Madrid, Spain).

\section{Tissue incubations}

For the analysis of the direct effects of leptin on steroidogenic-related genes, static incubation of testicular tissue was carried out as described elsewhere (Tena-Sempere et al. 1999a, 2000a). This setting allows up to $4 \mathrm{~h}$ of incubation of slices of testicular tissue of approximately $20 \cdot 0 \mathrm{~mm}$ thickness with preserved cell viability, as indirectly evidenced by appropriate secretory responses to known stimuli and absence of significant RNA breakdown in incubated samples (Tena-Sempere et al. 1999a, $2000 a$, and present results). Upon decapitation of experimental animals, testes were removed immediately, decapsulated, and cut into pieces of approximately equal size (mean weight/piece: $383 \pm 8.5 \mathrm{mg} ; 4$ slices per testis). Testicular slices (2 slices/well) were incubated in $2 \mathrm{ml}$ DMEM-F12 medium (1:1; Life Technologies, Grand Island, NY, USA) supplemented with $0.1 \mathrm{~g} / 1$ gentamicin (Biological Industries, Bet-Haemek, Israel) in a Dubnoff shaker $\left(60\right.$ cycles $/ \mathrm{min}$ ) at $32{ }^{\circ} \mathrm{C}$ under an atmosphere of $5 \% \mathrm{CO}_{2}-95 \% \mathrm{O}_{2}$. After preincubation for $1 \mathrm{~h}$, the media were replaced either by fresh medium or medium containing increasing doses of human recombinant leptin $\left(10^{-9}-10^{-7} \mathrm{M}\right)$ in the presence of hCG $(10 \mathrm{IU} / \mathrm{ml})$. An additional group of testicular samples was challenged with hCG alone. After $180 \mathrm{~min}$ incubation, $100 \mu \mathrm{l}$ aliquots from the incubation media were taken for testosterone measurement and samples of testicular tissue were frozen 
in liquid nitrogen and stored at $-70{ }^{\circ} \mathrm{C}$ until used for RNA analysis. On the latter, four major targets were selected: steroidogenic factor 1 (SF-1), steroidogenic acute regulatory protein (StAR), cytochrome $\mathrm{P} 450$ cholesterol side-chain cleavage enzyme (P450 scc) and $17 \beta$-hydroxy steroid dehydrogenase type III (17 $\beta$-HSD).

\section{Testosterone measurements}

Testosterone was measured from diethyl ether extracts of tissue incubation media by RIA using ${ }^{3} \mathrm{H}$-labeled testosterone as tracer, as described elsewhere (Rodriguez-Padilla et al. 1987). The levels of testosterone in the media were expressed as normalized values per gram of incubated tissue.

\section{RNA isolation and Northern blot analysis}

Total RNA was isolated from testicular samples using the single-step acid guanidinium thiocyanate-phenolchloroform extraction method, as described previously (Chomczynski \& Sacchi 1987). The quantity of extracted RNA was assessed by spectrophotometry.

For Northern hybridization analyses, RNA samples (20 $\mu \mathrm{g} /$ lane) were resolved on $1 \cdot 2 \%$ denaturing agarose gels and transferred onto Hybond- $\mathrm{N}^{+}$nylon membranes (Amersham International, Aylesbury, UK) using the capillary method. The membranes were cross-linked by short-wave UV irradiation and prehybridized for $4-6 \mathrm{~h}$ at $64{ }^{\circ} \mathrm{C}$ in a solution containing $50 \%$ deionized formamide, $3 \times \mathrm{SSC}, 5 \times$ Denhardt's solution, $0 \cdot 1 \mathrm{~g} / 1$ heat-denatured calf thymus DNA, $1 \%$ SDS, and $0 \cdot 1 \mathrm{~g} / 1$ yeast transfer RNA. For hybridization, ${ }^{32} \mathrm{P}-$ labeled complementary RNA (cRNA) and DNA (cDNA) probes specific for the target genes were generated using the Riboprobe system II kit and the Prime-a-Gene labeling kit (Promega, Madison, WI, USA), respectively. For generation of cRNA probes, NotI linearized pGEM-T vector (Promega) containing the full-length mouse StAR cDNA, and EcoRI linearized pBS plasmid (Promega) containing a $298 \mathrm{bp}$ fragment of rat P450 scc cDNA were used as templates. In vitro transcription was carried out using T7 RNA polymerase, and $\left[{ }^{32}\right.$ P]UTP (Amersham), following the instructions of the manufacturer. For generation of cDNA probes, EcoRIPstI $780 \mathrm{bp}$ fragment of rat SF-1 cDNA, and EcoRI excised $367 \mathrm{bp}$ fragment of mouse $17 \beta-H S D$ type III (Mustonen et al. 1997) were used as templates. Random priming was carried out using DNA polymerase I (Klenow fragment) and $\left[{ }^{32} \mathrm{P}\right] \mathrm{CTP}$ (Amersham), following instructions of the manufacturer.

Hybridizations were carried out at $66^{\circ} \mathrm{C}$ (cRNA probes) or $42{ }^{\circ} \mathrm{C}$ (cDNA probes) for $20 \mathrm{~h}$ in the same prehybridization solution after addition of the corresponding radiolabeled probe. After hybridization, the membranes were washed in $2 \times \mathrm{SSC}-0 \cdot 1 \% \mathrm{SDS}$ at room temperature for $20 \mathrm{~min}, 0.5 \times \mathrm{SSC}-0 \cdot 1 \% \mathrm{SDS}$ for $20 \mathrm{~min}$ at $65{ }^{\circ} \mathrm{C}$, and three times in $0 \cdot 1 \% \mathrm{SSC}-0 \cdot 1 \% \mathrm{SDS}$ for $1 \mathrm{~h}$ at $65^{\circ} \mathrm{C}$. The filters were exposed to Kodak X-ray films (Kodak XAR-5 and XLS 5, Eastman Kodak, Rochester, NY, USA) at $-70{ }^{\circ} \mathrm{C}$ for $24-120 \mathrm{~h}$. Relative mRNA levels were obtained by densitometric scanning of the autoradiograms (1-D Manager software, TDI Ltd, Madrid, Spain), and the values were normalized by the amount of $18 \mathrm{~S}$ ribosomal RNA transferred per lane, as estimated under ethidium bromide staining. The molecular sizes of the mRNA species were estimated by comparison with mobility of the $18 \mathrm{~S}$ and $28 \mathrm{~S}$ ribosomal RNAs. Reagents for RNA analysis were obtained from Sigma Chemical Co. (St Louis, MO, USA), unless otherwise stated.

\section{In situ hybridization}

Five micrometre sections of adult testis tissue were used for in situ hybridization. To assess cellular distribution of overall $\mathrm{Ob}-\mathrm{R}$ gene expression, a specific riboprobe recognizing all $\mathrm{Ob}-\mathrm{R}$ isoforms was generated. An antisense ${ }^{35}$ S-labeled RNA probe complementary to an area of the extracellular domain of $\mathrm{Ob}-\mathrm{R}$ was synthesized using the Riboprobe system II kit (Promega), SP6 RNA polymerase, $\left[{ }^{35} \mathrm{~S}\right] \mathrm{CTP}$, and NcoI-linearized template, constructed by subcloning a $418 \mathrm{bp}$ fragment of $\mathrm{Ob}-\mathrm{R}$ cDNA into pGEM-T vector. This cDNA was generated by RT-PCR, using the primer pair Ob-Rsense $\left(5^{\prime}-\mathrm{CTC}\right.$ CGC ACT CAC AGG CAA CA-3') and Ob-Ras (5'-TGG ATC GGG CTT CAC AAC AA-3'). As control, adjacent sections were hybridized using a sense radiolabeled RNA probe generated as described above except for the use of SpeI-linearized template and T7 RNA polymerase. Pretreatment of sections was performed as described previously (Tena-Sempere et al. 1994). The hybridization of pre-treated slides with antisense or sense probes was carried out overnight at $50{ }^{\circ} \mathrm{C}$, and thereafter the samples were washed first in $2 \times \mathrm{SSC}, 50 \%$ formamide, $10 \mathrm{nM}$ dithiothreitol (DTT; Boehringer Mannheim, Ingelheim, Germany) at $50{ }^{\circ} \mathrm{C}$ for $30 \mathrm{~min}$, and then in $0.2 \times \mathrm{SSC}, 50 \%$ formamide, $10 \mathrm{nM}$ DTT at $50{ }^{\circ} \mathrm{C}$ for $10 \mathrm{~min}$. The slides were rinsed with $1 \times \mathrm{PBS}$ and treated with $10 \mu \mathrm{g} / \mathrm{ml}$ ribonuclease A (Boehringer Mannheim) in Tris-EDTA buffer $\left(\mathrm{T}_{10} \mathrm{E}_{5}\right), 0.5 \mathrm{M} \mathrm{NaCl}(\mathrm{pH} 8 \cdot 0)$ at $37^{\circ} \mathrm{C}$ for $30 \mathrm{~min}$. After digestion, washing with $2 \times$ SSC, $50 \%$ formamide, $10 \mathrm{nM}$ DTT was repeated. Finally, the slides were rinsed with $2 \times$ SSC, dehydrated in ethanol, and processed for liquid emulsion autoradiography using NTB-3 emulsion solution (Eastman Kodak). The slides were exposed at $4{ }^{\circ} \mathrm{C}$ for $2-3$ weeks, and developed at $12{ }^{\circ} \mathrm{C}$ by treatment with $\mathrm{D}-19$ solution (Eastman Kodak) for $2.5 \mathrm{~min}$. After developing, the slides were counterstained with hematoxylin (BDH Ltd, Poole, UK).

\section{$R N A$ analysis by semi-quantitative RT-PCR}

The pattern of mRNA expression of Ob-R isoforms in adult rat testis was assessed by semi-quantitative 
RT-PCR, using isoform-specific oligo-primer pairs. Total RNA was isolated from adult testicular samples as described above (Chomczynski \& Sacchi 1987). For amplification of $\mathrm{Ob}-\mathrm{R}$ variants, the following primer pairs were used: $O b-R a$ sense $\left(5^{\prime}-\mathrm{CCT}\right.$ ATC GAG AAA TAT CAG TTT A- $3^{\prime}$ ) and $\mathrm{Ob}-\mathrm{Ra}$ as (5'-TCA AAG AGT GTC CGC TCT CT-3'), for amplification of a $285 \mathrm{bp}$ fragment of rat $\mathrm{Ob}-\mathrm{Ra}$ isoform $\mathrm{cDNA} ; \mathrm{O} b-\mathrm{Rb}$ sense (5'-TGG CCC ATG AGT AAA GTG AAT-3') and $O b-R b$ as $\left(5^{\prime}\right.$-CCA GAA GAA GAG GAC CAA ATA $\left.-3^{\prime}\right)$, for amplification of a $386 \mathrm{bp}$ fragment of rat $\mathrm{Ob}-\mathrm{Rb}$ isoform cDNA; $O b-R c$ sense (5'-GTG TCC TGC TGC TCG GAA CAC TGT- $\left.3^{\prime}\right)$ and $\mathrm{Ob}-\mathrm{Rc}$ as (5'-AAA GAT CTC TAT GTA ATA GAG TAT-3'), for amplification of a $188 \mathrm{bp}$ fragment of rat $\mathrm{Ob}-\mathrm{Rc}$ isoform cDNA; $\mathrm{Ob}$-Re sense (5'-GCA GAA TCA GCA CAC ACT GTT-3') and Ob-Re as $\left(5^{\prime}\right.$-GTA AAA GCA CAG TAC ACA TAC C- $3^{\prime}$ ), for amplification of a 301-bp fragment of rat Ob-Re isoform cDNA; and Ob-Rf sense (5'-AGA GGA TAT ATA GTG GAT GCC G-3') and Ob-Rf as (5'-CAC AAA TGA GCC ATC TTC AAA CC-3'), for amplification of a $411 \mathrm{bp}$ fragment of rat $\mathrm{Ob}-\mathrm{Rf}$ isoform cDNA. The reported sets of primers were selected based on previous references (Garcia et al. 2000) with minor modifications, and synthesized according to the published cDNA sequences of the cloned Ob-R isoforms (Tartaglia et al. 1995, Lee et al. 1996, Takaya et al. 1996, Tartaglia 1997). In addition, to provide an appropriate internal control, co-amplification of a $290 \mathrm{bp}$ fragment of the L19 ribosomal protein mRNA was carried out in each sample using the primer pair: L19-sense (5'-GAA ATC GCC AAT GCC AAC TC-3') and L19-as (5'-ACC TTC AGG TAC AGG CTG TG-3'), generated according to the rat L19 ribosomal protein cDNA (Chang et al. 1987).

For amplification of the targets, RT and PCR were run in two separate steps. Furthermore, to enable appropriate amplification in the exponential phase for each target, PCR amplification of Ob-Ra, -Rb, -Rc, -Rf, -Re and L19 ribosomal protein transcripts was carried out in separate reactions with different number of cycles (see below), but using similar amounts of the corresponding cDNA templates, generated in single $\mathrm{RT}$ reactions, as described elsewhere (Santana et al. 1996, Tena-Sempere et al. 2000b). Briefly, equal amounts of total testicular RNA $(4 \mu \mathrm{g})$ were heat denatured and reverse transcribed by incubation at $42{ }^{\circ} \mathrm{C}$ for $90 \mathrm{~min}$ with $12.5 \mathrm{U}$ AMV RT (Promega), $20 \mathrm{U}$ ribonuclease inhibitor RNasin (Promega), $200 \mathrm{nM}$ deoxy-NTP mixture, and $1 \mathrm{nM}$ isoform-specific and L19 antisense primers, in a final volume of $30 \mu \mathrm{l}$ of $1 \times \mathrm{AMV}-\mathrm{RT}$ buffer. The reactions were terminated by heating at $97^{\circ} \mathrm{C}$ for $5 \mathrm{~min}$ and cooling on ice, followed by dilution of the RT cDNA samples with nuclease-free $\mathrm{H}_{2} \mathrm{O}$ (final volume $60 \mu \mathrm{l}$ ). For semiquantitative PCR, $10 \mu \mathrm{l}$ aliquots of the cDNA samples (equivalent to $650 \mathrm{ng}$ total RNA input) were amplified in $50 \mu \mathrm{l}$ of $1 \times$ PCR buffer in the presence of $2.5 \mathrm{U}$
Taq-DNA polymerase (Promega), $200 \mathrm{nM}$ deoxy-NTP mixture, and the appropriate primer pairs $(1 \mathrm{nM}$ of each primer; see above). PCR reactions consisted of a first denaturing cycle at $97^{\circ} \mathrm{C}$ for $5 \mathrm{~min}$, followed by a variable number of cycles of amplification defined by denaturation at $96{ }^{\circ} \mathrm{C}$ for $1.5 \mathrm{~min}$, annealing at $55^{\circ} \mathrm{C}$ for $1.5 \mathrm{~min}$, and extension at $72{ }^{\circ} \mathrm{C}$ for $3 \mathrm{~min}$. A final extension cycle of $72{ }^{\circ} \mathrm{C}$ for 15 min was included. The number of cycles was optimized to ensure amplification in the exponential phase of PCR. Different numbers of cycles were tested for each Ob-R isoform (ranging between 25 and 45) and L19 ribosomal protein (ranging between 14 and 30). Based on the analysis of cycle dependency of the intensity of the generated PCR signals, 33 and 20 cycles were chosen for further analysis of Ob-R variants and L19 ribosomal protein transcript, respectively.

The cDNA fragments generated were resolved in 1.5\% agarose gels containing ethidium bromide $(0 \cdot 1 \mu \mathrm{g} / \mathrm{ml})$, and visualized using a digital imaging system (1-D Manager software, TDI Ltd). The molecular sizes of the transcripts were determined by comparison with size markers run together with the cDNA products (PCR $50 \mathrm{bp}$ Step Ladder, Promega). Specificity of the PCR products was confirmed by Southern hybridization, using radiolabeled nested oligo-primers and/or digestion with specific restriction enzymes (data not shown), as described elsewhere (Tena-Sempere et al. 1999b, García et al. 2000). To ensure that equal inputs of RNA were added to RT-PCR reactions, only samples yielding roughly similar optical density (OD) values for L19 bands were considered for further analysis. In addition, to minimize potential RT-PCR artefacts due to inherent reaction variability, all data points were repeated, for each target, at least 3 times using independent RNA samples. Finally, in all assays, liquid controls and reactions without RT were included, yielding negative amplification (data not shown).

\section{Statistics}

Hormonal results from testicular incubations are presented as means \pm S.E.M. from $8-12$ independent determinations. When appropriate, semiquantitative data from RNA analyses were expressed as means \pm s.E.M. from at least three independent determinations. Significant differences between groups were determined by one-way ANOVA, followed by Tukey's test. $P<0 \cdot 05$ was considered significant.

\section{Results}

Expression of several steroidogenic-related genes is regulated by leptin in adult rat testis

To identify potential targets for leptin-induced inhibition of testosterone secretion, secretory responses were 
Table 1 Effects of human recombinant (hr) leptin on in vitro hCG-stimulated testosterone (T) secretion by adult rat testicular slices. The testicular samples were challenged with increasing concentrations of leptin $\left(10^{-9}-10^{-7} \mathrm{M}\right)$ in the presence of $10 \mathrm{IU} / \mathrm{ml} \mathrm{hCG}$, and testosterone release to the incubation medium was assessed after $180 \mathrm{~min}$ (see Materials and Methods). Testes incubated with $10 \mathrm{lU} / \mathrm{ml}$ hCG served as controls. In addition, testosterone secretion by testicular samples incubated in the presence of medium (DMEM) alone is presented. Values are given as means \pm S.E.M. $(n=10-12$ samples/group $)$

\begin{tabular}{ll} 
& $\begin{array}{l}\text { T secretion } \\
((\mathrm{ng} / \mathrm{ml}) \cdot \mathrm{g} \text { tissue })\end{array}$ \\
\cline { 2 - 2 } DMEM & $13 \cdot 46 \pm 1 \cdot 34$ \\
hCG 10 IU & $210 \cdot 5 \pm 22 \cdot 5^{\mathrm{a}}$ \\
hCG + hr leptin $10^{-9} \mathrm{M}$ & $164 \cdot 2 \pm 18 \cdot 7^{\mathrm{a}, *}$ \\
hCG + hr leptin $10^{-8} \mathrm{M}$ & $140 \cdot 7 \pm 17 \cdot 5^{\mathrm{a}, * *}$ \\
hCG + hr leptin $10^{-7} \mathrm{M}$ & $147 \cdot 1 \pm 10 \cdot 2^{\mathrm{a}, * *}$
\end{tabular}

a $P \leq 0 \cdot 01$ vs values from DMEM group; ${ }^{*} P \leq 0 \cdot 05 ;{ }^{* *} P \leq 0 \cdot 01$ vs values from the corresponding hCG-stimulated group (ANOVA followed by Tukey's test).

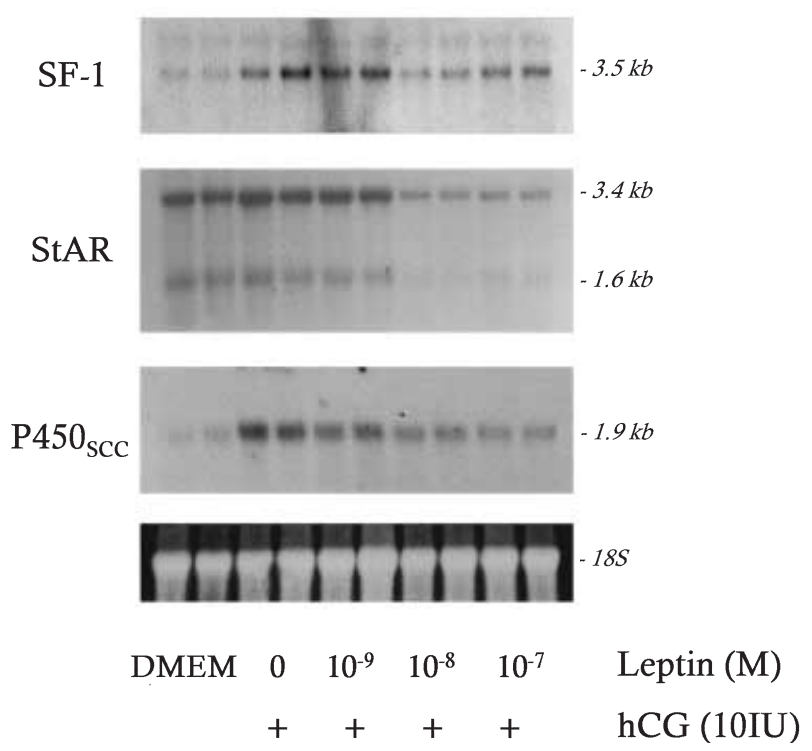

Figure 1 Representative Northern hybridization analyses of steroidogenic factor-1 (SF-1), steroidogenic acute regulatory protein (StAR) and cytochrome P450 cholesterol side-chain cleavage enzyme (P450 scc) mRNA expression levels in individual testicular samples incubated in the presence of increasing doses of recombinant leptin $\left(10^{-9}-10^{-7} \mathrm{M}\right)$ plus hCG $(10 \mathrm{IU} / \mathrm{ml})$. Samples incubated in the presence of hCG served as controls. In addition, data from samples incubated with medium (DMEM) alone are presented. Two samples per treatment group are shown. Northern hybridizations were carried out using specific complementary RNA and DNA probes, as described in Materials and Methods. For each sample, the amount of $18 \mathrm{~S}$ ribosomal RNA transferred per lane was used as control for even loading and transfer efficiency. The molecular sizes of the expected mRNA species are indicated on the right. correlated to mRNA expression levels of several steroidogenic key factors in hCG-stimulated testicular samples after exposure to increasing doses of human recombinant leptin $\left(10^{-9}-10^{-7} \mathrm{M}\right)$. The mRNAs to be analyzed were selected based on previous references on the effects of leptin upon other steroidogenic tissues (Kruse et al. 1998, Zachow et al. 1999), as well as on their pivotal role in testosterone biosynthesis (Stocco \& Clark 1996, Parker \& Schimmer 1997). RNA analyses were carried out by Northern hybridization using specific cRNA and cDNA probes. Hybridization signals of $3.5 \mathrm{~kb}, 3.4$ and $1.6 \mathrm{~kb}$, $1.9 \mathrm{~kb}$, and $1.3 \mathrm{~kb}$ were obtained for SF-1, StAR, P450 scc and 17ß-HSD type III, respectively, in agreement with previous reports (Miller 1988, Mustonen et al. 1997, Clark et al. 1995, Manna et al. 1999b, Tsai-Morris et al. 1999). In keeping with our previous data (Tena-Sempere et al. 1999a), $180 \mathrm{~min}$ incubation of testicular tissue in the presence of $10 \mathrm{IU} / \mathrm{ml}$ hCG elicited a significant increase in testosterone secretion. This response was significantly inhibited by co-incubation with leptin, at all doses tested $\left(10^{-9}-10^{-7} \mathrm{M}\right.$; Table 1$)$. In this experimental setting, hCG significantly increased the steady-state mRNA levels of SF-1, StAR and P450 scc, as estimated by Northern hybridization after $180 \mathrm{~min}$ stimulation, whereas the expression level of $17 \beta-$ HSD type III mRNA remained unchanged. Exposure to recombinant leptin induced a co-ordinate decrease in the hCG-stimulated expression levels of SF-1, StAR and P450 scc mRNAs. However, subtle differences in the dose dependency of this effect were noted: $10^{-9} \mathrm{M}$ leptin moderately inhibited hCGelicited P450 scc mRNA levels without altering those of SF-1 and StAR, while $10^{-8}-10^{-7} \mathrm{M}$ doses significantly decreased mRNA levels of the three targets. On the latter, it has to be noted that no significant difference in the magnitude of such an inhibitory response was detected between $10^{-8}$ and $10^{-7} \mathrm{M}$ leptin concentrations for any of the messages under evaluation. On the contrary, recombinant leptin, at all doses tested, failed to modify the 17ß-HSD type III mRNA levels in hCG-stimulated testicular samples (Figs 1-3).

Pattern of cellular distribution and isoform expression of $O b-R$ $m R N A$ in adult rat testis

To provide further insight into the mode of action of leptin in rat testis, the pattern of cellular expression of leptin receptor $(\mathrm{Ob}-\mathrm{R})$ mRNA was explored in testicular sections from adult (75-day-old) rats by means of in situ hybridization (ISH), using a specific antisense RNA probe complementary to all $\mathrm{Ob}-\mathrm{R}$ isoforms. Distribution analysis revealed a scattered pattern of $\mathrm{Ob}-\mathrm{R}$ gene expression within rat testis, hybridization signals being detected in the seminiferous tubules and in the interstitial space (Fig. 4A). At higher magnification, specific signals were clearly located in Leydig and Sertoli cells (Fig. 4B), with possible deposition of silver grains in germ cells also. Specificity of 


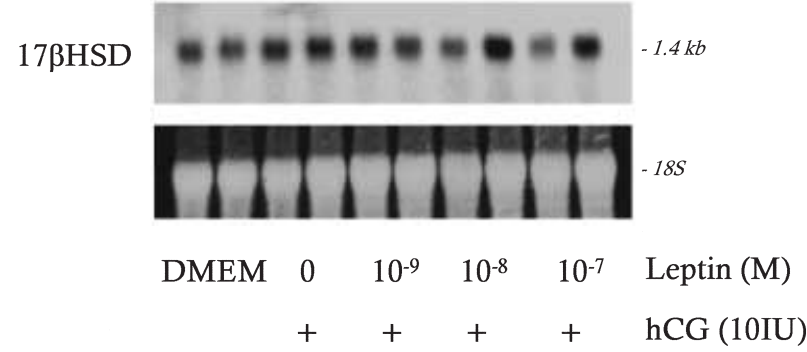

Figure 2 Representative Northern hybridization analysis of $17 \beta$-hydroxy steroid dehydrogenase type III (17 $\beta$-HSD) mRNA expression levels in individual testicular samples incubated in the presence of increasing doses of recombinant leptin $\left(10^{-9}-10^{-7} \mathrm{M}\right)$ plus hCG $(10 \mathrm{IU} / \mathrm{ml})$. Samples incubated in the presence of hCG served as controls. In addition, data from samples incubated with medium (DMEM) alone are presented. Two samples per treatment group are shown. Northern hybridizations were carried out using a specific complementary DNA probe, as described in Materials and Methods. For each sample, the amount of $18 \mathrm{~S}$ ribosomal RNA transferred per lane is presented, and the molecular size of the expected mRNA species is indicated on the right.

the ISH results was confirmed by hybridization of adjacent testicular sections with the corresponding sense cRNA probe, that yielded negative results (Fig. 4C).

In addition, to characterize further the pattern of $\mathrm{Ob}-\mathrm{R}$ gene expression in adult rat testis, the relative mRNA levels of the different $\mathrm{Ob}-\mathrm{R}$ subtypes were assayed by means of semi-quantitative RT-PCR. Such an analysis, using isoform-specific primer pairs, revealed that $\mathrm{Ob}-\mathrm{Rb}$ mRNA was abundantly expressed in the adult (75-dayold) rat testis. In addition, variable expression levels of mRNAs encoding $\mathrm{Ob}-\mathrm{Ra}, \mathrm{Ob}-\mathrm{Re}$, and $\mathrm{Ob}-\mathrm{Rf}$ isoforms were detected, whereas almost negligible signals for Ob-Rc were amplified (Fig. 5).

\section{Discussion}

Testicular steroid hormone biosynthesis is a hormonally regulated multi-step process that involves the sequential conversion of cholesterol into testosterone by the coordinated actions of a group of cytochrome P450 hydroxylase and hydroxysteroid dehydrogenase enzymes (Miller 1988). The first and rate-limiting key steps of this cascade are the translocation of cholesterol to the inner mitochondrial membrane and its subsequent conversion into pregnenolone; events that are mediated by steroidogenic acute regulatory (StAR) protein and cytochrome P450 cholesterol side-chain cleavage (P450 scc) enzyme, respectively (Miller 1988, Stocco \& Clark 1996). In rodent testis, the predominant $\Delta^{4}$ steroidogenic pathway ends with the conversion of androstenedione to testosterone by the specific testicular type III isoform of $17 \beta$-hydroxysteroid dehydrogenase (17 $\beta-H S D)$ (Mustonen et al. 1997,
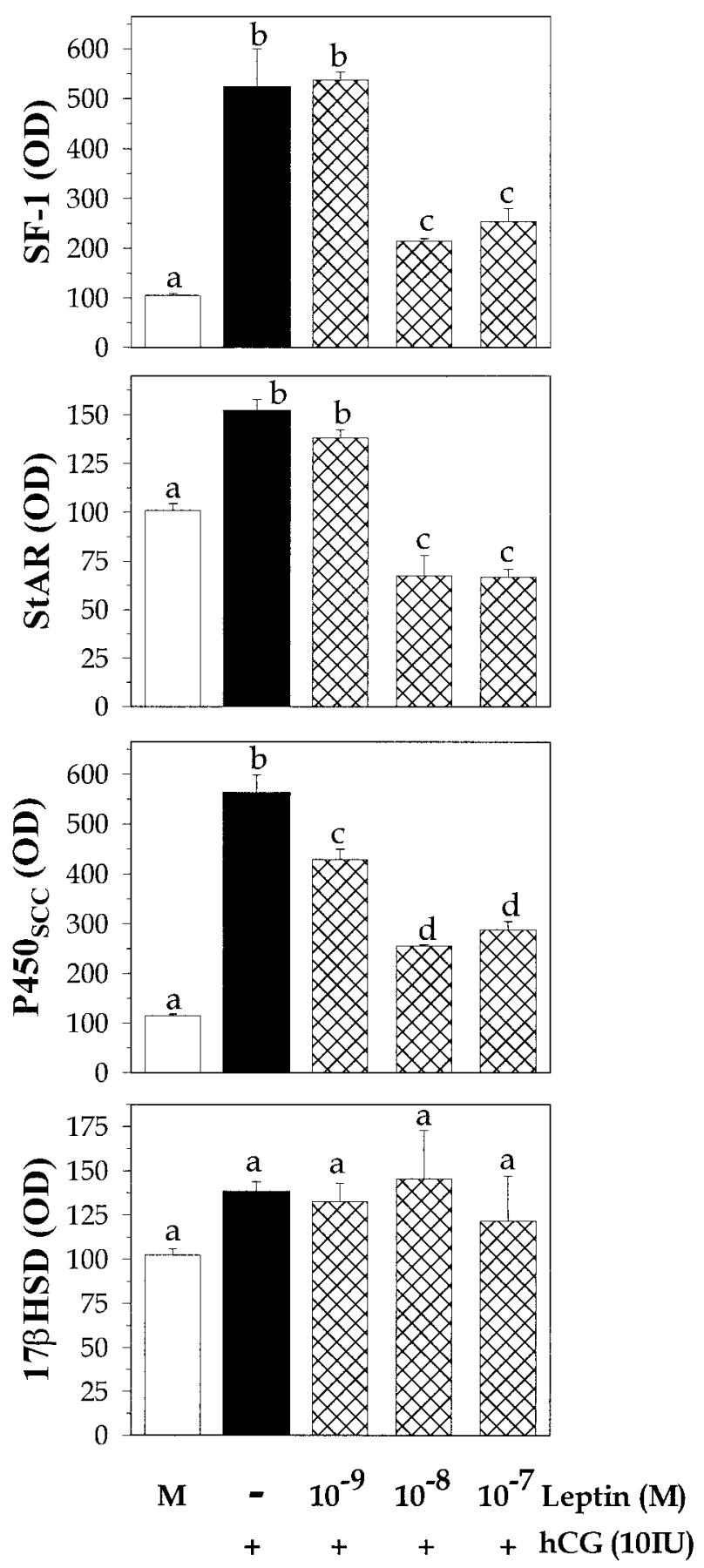

Figure 3 Compilation of quantitative data on the steady-state levels of SF-1, StAR, P450 scc and 17 $\beta$-HSD mRNAs in hCG-stimulated testicular samples challenged with increasing concentrations of recombinant leptin $\left(10^{-9}-10^{-7} \mathrm{M}\right)$. Relative expression levels were obtained, in each sample, by normalization of absolute optical densities (OD) of each target to that of $18 \mathrm{~S}$ ribosomal RNA transferred per lane. Values are given as means \pm S.E.M. of at least three independent determinations. Groups with different superscript letters are statistically different (ANOVA followed by Tukey's test). 

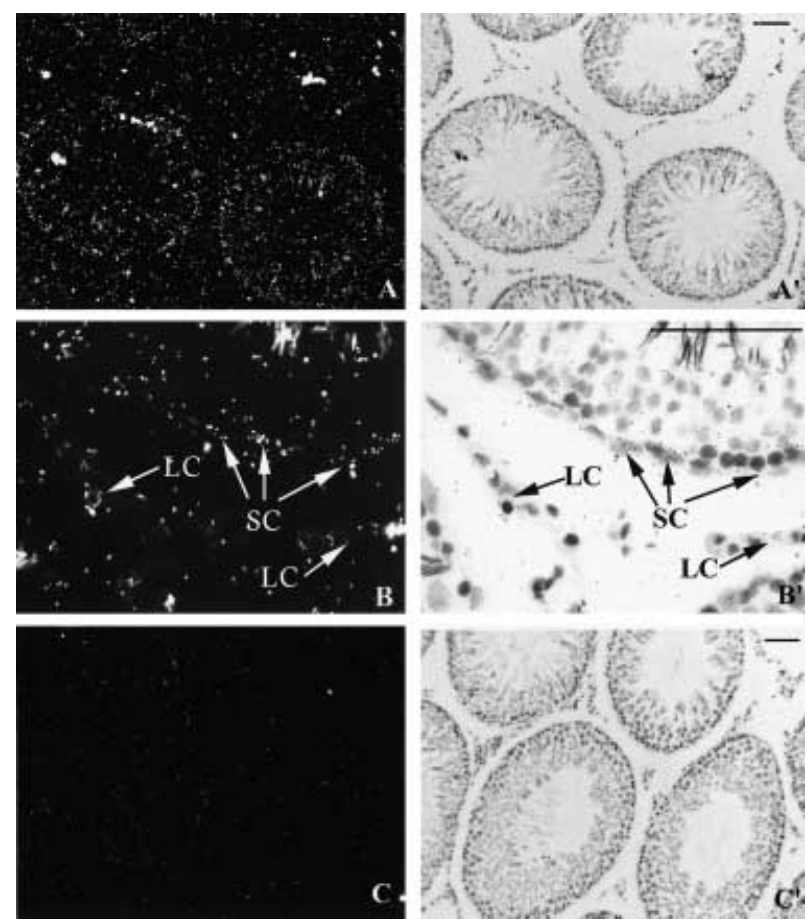

Figure 4 Representative photomicrographs of Ob-R mRNA in situ hybridization of adult rat testis. Testicular sections from 75-day-old rats were hybridized with a specific antisense RNA probe complementary to all Ob-R isoforms, as described in Materials and Methods. Darkfield (A, B, C) and brightfield $\left(\mathrm{A}^{\prime}, \mathrm{B}^{\prime}, \mathrm{C}^{\prime}\right)$ photomicrographs are presented. The arrows in $B$ and $B^{\prime}$ indicate Leydig cells (LC) and Sertoli cells (SC). An adjacent section hybridized with the corresponding sense CRNA probe is shown in C. The emulsion-coated slides were exposed in the dark for 2-3 weeks at $4{ }^{\circ} \mathrm{C}$. Scale bars in $A^{\prime}, B^{\prime}$ and $C^{\prime}=50 \mu \mathrm{m}$.

Tsai-Morris et al. 1999). Tissue-specific and hormoneregulated expression of the pivotal elements in the steroidogenic pathway is likely depend on the concerted action of several transcription factors. Among them, a crucial role for steroidogenic factor 1 (SF-1) has recently emerged not only as a transcriptional regulator of various steroidogenic enzyme genes, but also as a pivotal element in gonadal and adrenal development and function (Parker \& Schimmer 1997, Hammer \& Ingraham 1999).

Compelling evidence demonstrates direct inhibitory actions of leptin upon steroid hormone secretion. Such effects have been independently reported by different groups in the three major steroidogenic tissues, namely the adrenal gland, the ovary and the testis (Spicer \& Francisco 1997, Pralong et al. 1998, Kruse et al. 1998, Caprio et al. 1999, Tena-Sempere et al. 1999a, 2000a, Zachow et al. 1999). However, the mechanisms for such an inhibitory action are only partially characterized, and little attention has been paid to the molecular events involved in leptininduced inhibition of testicular testosterone secretion. To gain insight into the mechanisms whereby leptin suppresses testosterone secretion in vitro, we correlated the secretory responses to mRNA expression levels of SF-1, StAR, P450 scc and 17 $\beta$-HSD in hCG-stimulated testicular samples after exposure to increasing doses of human recombinant leptin $\left(10^{-9}-10^{-7} \mathrm{M}\right)$. Results from our Northern hybridization analyses suggest that decreased expression of mRNAs encoding several up-stream elements in the steroidogenic route may contribute, at least partially, to leptin-induced inhibition of testicular steroidogenesis.

The pivotal role of cytochrome P450 scc in steroid hormone biosynthesis makes it a target for the regulatory actions of tropic hormones in steroidogenic tissues (Miller 1988). In addition, since leptin was recently reported to significantly reduce ACTH-stimulated P450 scc mRNA levels in cultured bovine adrenocortical cells (Kruse et al. 1998), we aimed at evaluating whether an analogous response is detected in adult rat testis. Indeed, our Northern analyses demonstrated a dose-dependent decrease in P450 scc mRNA expression levels in hCGstimulated rat testicular samples exposed for $180 \mathrm{~min}$ to 


\section{Ob-R isoforms}

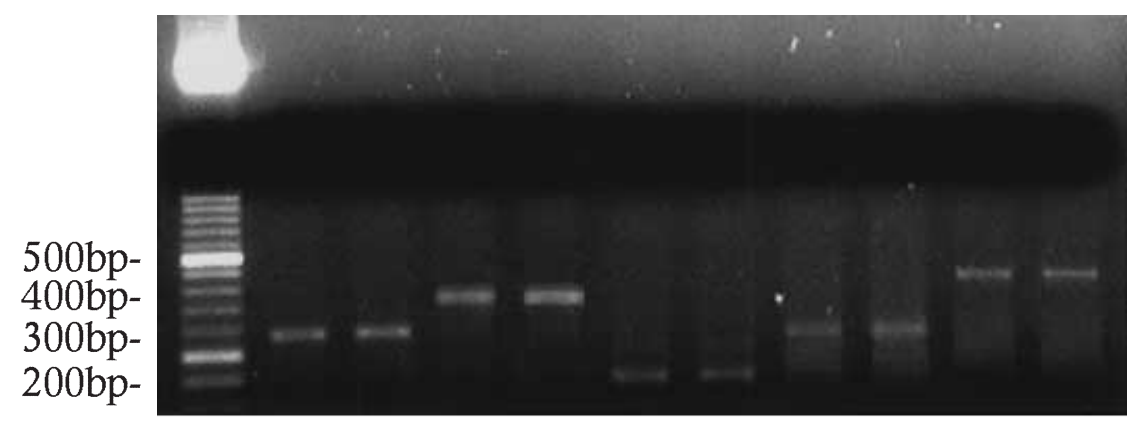

\section{Ob-Ra Ob-Rb Ob-Rc Ob-Re Ob-Rf}

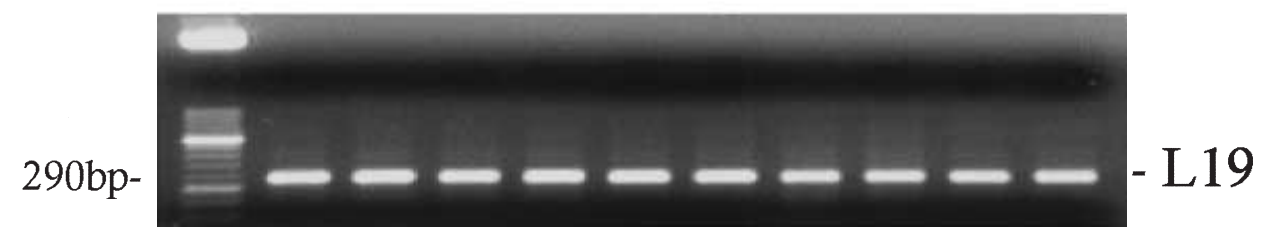

Figure 5 Assessment of expression levels of the mRNAs encoding Ob-Ra, Ob-Rb, Ob-Rc, Ob-Re and Ob-Rf subtypes in adult (75-day-old) rat testis. A representative ethidium bromide-stained gel electrophoresis of isoform specific Ob-R cDNA fragments, amplified by semi-quantitative RT-PCR, is presented. As internal control, amplification of L19 ribosomal protein transcript was carried out in each sample as described in Materials and Methods, yielding an even amplification pattern. The sizes of the generated products were calculated by comparison with the mobility of 50 bp DNA step ladder (M); the base pair length of representative markers being indicated on the left.

increasing concentrations of recombinant leptin. These data suggest that such a step in steroid hormone biosynthesis may be under leptin regulation in different steroidogenic tissues (i.e. adrenal and testis). Moreover, they open up the possibility that the mechanism by which leptin inhibits testosterone secretion may involve, at least partially, modulation of early events in the steroidogenic pathway. This is further supported by the dose-dependent leptin-induced decrease in StAR mRNA levels observed in the same samples. To our knowledge, this is the first study to report the inhibitory effect of leptin on the expression levels of StAR mRNA. Given that regulation of steroidogenesis by various hormonal signals is tightly correlated with concomitant changes in StAR gene expression in different experimental settings (Clark et al. 1995, Manna et al. 1999a,b), our present results suggest that leptin-induced decrease in StAR mRNA expression may contribute, at least partially, to the reported inhibition of testosterone secretion in vitro, and open up the possibility that StAR mRNA expression may be under leptin regulation in other steroidogenic tissues. However, further experimental work, including analysis of expression at the protein level, is needed to fully demonstrate the involvement of P450 scc and StAR in the reported inhibitory effect of leptin upon rat testicular steroidogenesis.

Recently, SF-1 has emerged as a pivotal regulator of development and function of the hypothalamic-pituitary- gonadal axis. Concerning steroid hormone production, SF-1 has a key role in tissue-specific transcriptional regulation of several steroid hydroxylases, including cytochrome P450 scc (Parker \& Schimmer 1997, Hammer \& Ingraham 1999). Moreover, expression of the StAR gene, as well as those encoding several non-cytochrome P450 enzymatic components of the steroidogenic pathway, are under SF-1 regulation (Parker \& Schimmer 1997, Hammer \& Ingraham 1999). Our initial observation on the ability of leptin to inhibit hCG-stimulated StAR and P450 scc mRNA levels in rat testicular tissue prompted us to evaluate whether SF-1 mRNA expression itself can be regulated by leptin. In fact, little is known about the hormonal regulation of SF-1 gene expression, and conflicting results on the ability of hCG and other stimuli of mouse Leydig cell steroidogenesis to modulate SF-1 mRNA levels have been reported (Chau et al. 1997, Manna et al. 1999a,b). In keeping with a previous reference (Manna et al. 1999b), our analysis demonstrated increased expression of testicular SF-1 mRNA after hCG stimulation in vitro. In this setting, incubation with increasing concentrations of recombinant leptin induced a significant, dose-dependent decrease in the expression levels of SF-1 mRNA, i.e. a response roughly similar to that observed in terms of StAR and P450 scc mRNAs. Considering that expression of these targets is activated by SF-1, it is possible, although yet to be proven, that 
leptin-induced suppression of SF-1 expression levels may contribute, at least partially, to the decrease in StAR and P450 scc mRNA expression after exposure to leptin. Nevertheless, our results suggest that leptin is a novel regulator of SF-1 mRNA expression in rat testis. It remains to be solved whether a similar role is carried out in other tissues, such as the adrenal, the ovary, the ventromedial hypothalamus and the pituitary, where coexpression of functional Ob-Rs (Schwartz et al. 1996, Casanueva \& Dieguez 1999, Jin et al. 2000) and the SF-1 gene (Parker \& Schimmer 1997, Hammer \& Ingraham 1999) has been demonstrated.

Analysis of the molecular mechanisms whereby leptin inhibits estradiol production in the ovary demonstrated that leptin impairs stimulated P450 aromatase activity and mRNA expression, i.e. the final steroidogenic step in rat granulosa cells (Zachow et al. 1999). In order to explore the possibility that an analogous mechanism could operate in rat testis, leptin effects on mRNA expression levels of $17 \beta-$ HSD type III were evaluated. This was considered relevant given the recent cloning of the enzyme isoform in the rat and the limited knowledge available on hormonal regulation of expression of this target gene (Tsai-Morris et al. 1999). Our analyses demonstrated the lack of effect of $180 \mathrm{~min}$ exposure to hCG in vitro in terms of $17 \beta-\mathrm{HSD}$ type III mRNA levels. This is in keeping with a previous report showing that hCG-induced down-regulation of $17 \beta-$ HSD expression in vivo becomes evident only after $12 \mathrm{~h}$ treatment (Tsai-Morris et al. 1999). In addition, our results indicate that leptin is unable to acutely regulate $17 \beta-H S D$ type III mRNA expression levels in hCGstimulated testicular tissue. Thus, although the possibility of a regulatory action of leptin at this level cannot be completely ruled out on the basis of the present data, our results are suggestive of a possible sexual dimorphism in the overall mechanism whereby leptin inhibits gonadal sex steroid secretion.

Clearly, our current data do not exclude other possible sites of inhibitory action of leptin in testosterone biosynthesis. In fact, it was recently reported that leptin is able to decrease the 17,20 lyase activity in primary cultures of rat Leydig cells, thus decreasing the rate of conversion of 17-OH-progesterone into androstenedione (Caprio et al. 1999). However, since no acute changes in mRNA expression levels of cytochrome P450c17 after leptin stimulation were observed (Caprio et al. 1999), we did not analyze the potential regulation of this message by recombinant leptin in our experimental setting.

To expand our knowledge on the mode of action of leptin on adult rat testis, the pattern of cellular expression of leptin receptor $(\mathrm{Ob}-\mathrm{R})$ gene was evaluated by means of in situ hybridization (ISH) using a specific riboprobe complementary to all cloned $\mathrm{Ob}-\mathrm{R}$ isoforms. Worthy to note, most of the information on the location of $\mathrm{Ob}-\mathrm{R}$ in rodent testis comes from studies using the mouse, and species differences may exist. Our distribution analysis revealed a scattered pattern of $\mathrm{Ob}-\mathrm{R}$ gene expression within rat testis, with specific hybridization signals detected in the seminiferous tubules and in the interstitial space. Indeed, at higher magnification, signals were located in apparent Leydig and Sertoli cells, with possible expression in germ cells also. These results are in line with previous evidence on the expression of the $\mathrm{Ob}-\mathrm{R}$ gene in murine Leydig cells, as detected by ISH (Hoggard et al. 1997) and RT-PCR (Caprio et al. 1999). In addition, the expression of $\mathrm{Ob}-\mathrm{R}$ in mouse germ cells has been reported very recently (El-Hefnawy et al. 2000). Overall, although data on testicular location of Ob-R protein are not provided, our current results on the pattern of cellular distribution of $\mathrm{Ob}-\mathrm{R}$ mRNA in adult rat testis may pave the way for further elucidation of the molecular basis for leptin action upon the steroidogenic machinery, either through direct or indirect actions on Leydig cells.

Finally, analysis of $\mathrm{Ob}-\mathrm{R}$ isoform expression was carried out in adult rat testis. RT-PCR assays using isoformspecific primer pairs revealed that the $\mathrm{Ob}-\mathrm{Rb}$ isoform is apparently the most abundant mRNA variant at this age, in line with previous references (Caprio et al. 1999). However, other $\mathrm{Ob}-\mathrm{R}$ subtype messages were detected, with moderate to high expression levels for Ob-Ra, $\mathrm{Ob}-\mathrm{Re}$, and $\mathrm{Ob}-\mathrm{Rf}$ isoforms, and nearly negligible signals for Ob-Rc; a pattern of expression that is roughly analogous to that of the prepubertal rat testis (Tena-Sempere et al. 2001). As a next step, we will aim at identifying the pattern of cellular distribution of $\mathrm{Ob}-\mathrm{R}$ isoforms within rat testis. Nevertheless, novel data on expression levels of the mRNAs encoding different $\mathrm{Ob}-\mathrm{R}$ variants in adult rat testis are relevant considering the different functional capacities of the Ob-R subtypes (Tartaglia et al. 1995, Lee et al. 1996, Takaya et al. 1996, Tartaglia 1997, Murakami et al. 1997, White et al. 1997, White \& Tartaglia 1999). Thus, the complex pattern of processing of $\mathrm{Ob}-\mathrm{R}$ mRNA in rat testis may result in the generation of different receptor isoforms with variable signaling ability, ranging from complete $(\mathrm{Ob}-\mathrm{Rb})$ to partial $(\mathrm{Ob}-\mathrm{Ra})$ or absent (Ob-Re and others). Moreover, the specific functional features of testis-expressed $\mathrm{Ob}-\mathrm{R}$ isoforms such as $\mathrm{Ob}-\mathrm{Ra}$, involved in leptin transport across biological barriers (Tartaglia 1997, Bjorbæk et al. 1998), and Ob-Re, as soluble leptin-binding protein (Tartaglia 1997), as well as the proposed interaction between $\mathrm{Ob}-\mathrm{R}$ isoforms in leptin signaling (White et al. 1997, White \& Tartaglia 1999) should be taken into account when evaluating the mechanisms for testicular actions of leptin. In this context, identification of the specific roles of $\mathrm{Ob}-\mathrm{R}$ variants in rat testis merits further investigation.

In conclusion, our results demonstrate that $180 \mathrm{~min}$ exposure to leptin is able to down-regulate hCGstimulated SF-1, StAR and cytochrome P450 scc mRNA expression levels in adult rat testis without altering significantly those of $17 \beta-$ HSD type III. In addition, evidence for a scattered pattern of cellular expression of 
$\mathrm{Ob}-\mathrm{R}$ gene within rat testis is presented that includes $\mathrm{Ob}-\mathrm{Rb}$ as well as other shorter isoforms. Overall, decreased expression of mRNAs encoding several up-stream elements in the steroidogenic pathway may represent a novel contributing factor to leptin-induced inhibition of rat testicular steroidogenesis.

\section{Acknowledgements}

We thank Drs P Vihko and H Peltoketo (Biocenter and WHO Collaborating Centre for Research on Reproductive Health, Oulu, Finland) for donation of the mouse $17 \beta \mathrm{HSD}$ cDNA template. Leptin was a generous gift from Eli Lilly (Indianapolis, IN, USA). The authors are indebted to Rocío Campón and Inmaculada Aguilar for their excellent technical assistance. This work was supported by grant PM98-0163 from DGESIC (Ministerio de Educación y Cultura, Spain) and project 1FD97-0696-02 (FEDER).

\section{References}

Ahima R, Prabakaran D, Mantzoros C, Qu D, Lowell B, MaratosFlier E \& Flier J 1996 Role of leptin in the neuroendocrine response to fasting. Nature 382 250-252.

Ahima RS, Dushay J, Flier SN, Prabakaran D \& Flier JS 1997 Leptin accelerates the onset of puberty in normal female mice. Journal of Clinical Investigation 99 391-395.

Barash IA, Cheung CC, Weigle DS, Ren H, Kabigting ED, Kuijper JL, Clifton DK \& Steiner RA 1996 Leptin is a metabolic signal to the reproductive system. Endocrinology 137 3144-3147.

Bjorbæk C, Elmquist JK, Michl P, Ahima RS, van Bueren A, McCall AL \& Flier JS 1998 Expression of leptin receptor isoforms in rat brain microvessels. Endocrinology 139 3485-3491.

Caprio M, Isidori AM, Carta AR, Moretti C, Dufau ML \& Fabbri A 1999 Expression of functional leptin receptors in rodent Leydig cells. Endocrinology 140 4939-4947.

Casanueva FF \& Dieguez C 1999 Neuroendocrine regulation and actions of leptin. Frontiers in Neuroendocrinology 20 317-363.

Chang X-L, Lin A, McNally J, Pelleg D, Meyuhas O \& Wool Y 1987 The primary structure of rat ribosomal protein L19. Journal of Biological Chemistry 262 1111-1115.

Chau YM, Crawford PA, Woodson KG, Polish JA, Olson LM \& Sadovsky Y 1997 Role of steroidogenic-factor 1 in basal and $3^{\prime}-5^{\prime}$-cyclic adenosine monophosphate-mediated regulation of cytochrome P450 side-chain cleavage enzyme in the mouse. Biology of Reproduction $\mathbf{5 7}$ 765-771.

Chehab FF, Mounzik K, Lu R \& Lim ME 1997 Early onset of reproductive function in normal female mice treated with leptin. Science 275 88-90.

Chomczynski P \& Sacchi N 1987 Single-step method of RNA isolation by acid guanidinium thiocyanate-phenol-chloroform extraction. Analytical Biochemistry 162 156-159.

Clark BJ, Soo S-C, Caron KM, Ikeda Y, Parker KL \& Stocco DM 1995 Hormonal and developmental regulation of the steroidogenic acute regulatory protein. Molecular Endocrinology 9 1346-1355.

Considine RV, Sinha MK, Heiman ML, Kriauciunas A, Stephens TW, Nyce MR, Ohanneisian JP, Marco CC, McKee LJ, Bauer TL \& Caro JF 1996 Serum immunoreactive leptin concentrations in normal-weight and obese humans. New England Journal of Medicine 334 292-295.
El-Hefnawy T, Ioffe S \& Dym M 2000 Expression of the leptin receptor during germ cell development in the mouse testis. Endocrinology 141 2624-2630.

Friedman JM \& Halaas JL 1998 Leptin and regulation of body weight in mammals. Nature 395 763-770.

García MD, Casanueva FF, Dieguez C \& Señaris RM 2000 Gestational profile of leptin messenger ribonucleic acid (mRNA) content in the placenta and adipose tissue in the rat, and regulation of the mRNA levels of the leptin receptor subtypes in the hypothalamus during pregnancy and lactation. Biology of Reproduction 62 698-703.

Hammer GD \& Ingraham HA 1999 Steroidogenic factor-1: its role in endocrine organ development and differentiation. Frontiers in Neuroendocrinology 20 199-223.

Hoggard N, Mercer JG, Rayner DV, Moar K, Trayhurn P \& Williams LM 1997 Localization of leptin receptor mRNA splice variants in murine peripheral tissues by RT-PCR and in situ hybridization. Biochemical and Biophysical Research Communications 232 383-387.

Jin L, Zhang S, Burguera BG, Couce M, Osamura RY, Kulig E \& Lloyd RV 2000 Leptin and leptin receptor expression in rat and mouse pituitary cells. Endocrinology 141 333-339.

Kruse M, Bornstein SR, Uhlmann K, Paeth G \& Scherbaum WA 1998 Leptin down-regulates the steroid producing system in the adrenal. Endocrine Research 24 587-590.

Lee G, Proenca R, Montez JM, Carrol KM, Darvishzadeh JG, Lee JI \& Friedman JM 1996 Abnormal splicing of leptin receptor in diabetic mice. Nature 379 632-635.

Manna PR, Tena-Sempere M \& Huhtaniemi IT 1999a Molecular mechanisms of thyroid hormone-stimulated steroidogenesis in mouse Leydig tumor cells. Involvement of the steroidogenic acute regulatory (StAR) protein. Journal of Biological Chemistry 274 5909-5918

Manna PR, Pakarinen P, El-Hefnawy T \& Huhtaniemi IT 19996 Functional assessment of the calcium messenger system in cultured mouse tumor cells: regulation of human chorionic gonadotropininduced expression of the steroidogenic acute regulatory protein. Endocrinology 140 1739-1751.

Miller WL 1988 Molecular biology of steroid hormone synthesis. Endocrine Reviews 9 295-318.

Mounzih K, Lu R \& Chehab FF 1997 Leptin treatment rescues the sterility of genetically obese $o b / o b$ males. Endocrinology 138 1190-1193.

Murakami T, Yamashita T, Iida M, Kuwajima M \& Shima K 1997 A short form of leptin receptor performs signal transduction. Journal of Biological Chemistry 231 26-29.

Mustonen MVJ, Poutanen MH, Isomaa VV, Vihko PT \& Vihko RK 1997 Cloning of mouse $17 \beta$-hydroxysteroid dehydrogenase type 2, and analysing expression of the mRNAs for types 1, 2, 3, 4 and 5 in mouse embryos and adult tissues. Biochemical Journal 325 199-205.

Nagatani S, Guthukonda P, Thompson RC, Tsukamura H, Maeda KI \& Foster DL 1998 Evidence for GnRH regulation by leptin: leptin administration prevents reduced pulsatile LH secretion during fasting. Neuroendocrinology 67 370-376.

Parker KL \& Schimmer BP 1997 Steroidogenic factor 1: a key determinant of endocrine development and function. Endocrine Reviews 18 361-377.

Pralong FP, Roduit R, Waeber G, Castillo E, Mosimann F, Thorens B \& Gaillard RC 1998 Leptin inhibits directly glucocorticoid secretion by normal human and rat adrenal gland. Endocrinology 139 4264-4268.

Rodriguez-Padilla M, Bellido C, Pinilla L \& Aguilar E 1987 Secretion of LH in spontaneously hypertensive rats. Journal of Endocrinology $113255-260$.

Rosenbaum M \& Liebel RL 1998 Leptin: a molecule integrating somatic energy stores, energy expenditure and fertility. Trends in Endocrinology and Metabolism 9 117-123. 
Santana P, Llanes L, Hernández Y, González-Robayna Y, Tabraue C, González-Reyes J, Quintana J, Estévez F, Ruiz de Galarreta CM \& Fanjul LF 1996 Interleukin-1 $\beta$ stimulates sphingomyelin hydrolysis in cultured granulosa cells: evidence for a regulatory role of ceramide on progesterone and prostaglandin biosynthesis. Endocrinology 137 2480-2489.

Schwartz MW, Seeley RJ, Campfield A, Burn P \& Baskin DG 1996 Identification of targets of leptin action in rat hypothalamus. Journal of Clinical Investigation 98 1101-1106.

Spicer LJ \& Francisco CC 1997 The adipose obese gene product, leptin: evidence of a direct inhibitory role in ovarian function. Endocrinology 138 3374-3379.

Stocco DM \& Clark BJ 1996 Regulation of the acute production of steroids in steroidogenic cells. Endocrine Reviews 17 221-224.

Takaya K, Ogawa Y, Isse N, Okazaki T, Satoh N, Masuzaki H, Mori K, Tamura N, Hosoda K \& Nakao K 1996 Molecular cloning of rat leptin receptor isoform complementary DNAs-Identification of a missense mutation in Zucker fatty $(\mathrm{fa} / \mathrm{fa})$ rats. Biochemical and Biophysical Research Communications 225 75-83.

Tartaglia LA 1997 The leptin receptor. Journal of Biological Chemistry 272 6093-6096.

Tartaglia LA, Dembski M, Weng X, Deng N, Culpepper J, Devos R, Richards GJ, Campfield LA, Clark FT, Deeds J, Muir C, Sanker S, Moriarty A, Moore KJ, Smutko JS, Mays GG, Woolf EA \& Tepper RI 1995 Identification and expression cloning of a leptin receptor, OB-R. Cell 83 1263-1272.

Tena-Sempere M, Zhang F-P \& Huhtaniemi I 1994 Persistent expression of a truncated form of the luteinizing hormone receptor messenger ribonucleic acid in the rat testis after selective Leydig cell destruction by ethylene dimethane sulfonate. Endocrinology 135 1018-1024.

Tena-Sempere M, Pinilla L, González LC, Dieguez C, Casanueva FF \& Aguilar E 1999a Leptin inhibits testosterone secretion from adult rat testis in vitro. Journal of Endocrinology 161 211-218.

Tena-Sempere M, Kero J,Rannikko A \& Huhtaniemi I 19996 Experimental cryptorchidism induces a change in the pattern of expression of LH receptor mRNA in rat testis after selective Leydig cell destruction by ethylene dimethane sulfonate. Journal of Endocrinology 161 131-141.

Tena-Sempere M, Pinilla L, González LC, Navarro J, Dieguez C, Casanueva FF \& Aguilar E 2000a In vitro pituitary and testicular effects of leptin-related synthetic peptide, leptin ${ }_{116-130}$ amide, involve actions both similar to and distinct from those of the native leptin molecule in the adult rat. European Journal of Endocrinology 142 406-410.

Tena-Sempere M, Navarro J, Pinilla L, González LC, Huhtaniemi I \& Aguilar E $2000 b$ Neonatal exposure to estrogen differentially alters estrogen receptor $\alpha$ and $\beta$ messenger ribonucleic acid expression in rat testis during postnatal development. Journal of Endocrinology 165 345-357.

Tena-Sempere M, Pinilla L, Zhang F-P, González LC, Huhtaniemi I, Casanueva FF, Dieguez C \& Aguilar E 2001 Developmental and hormonal regulation of leptin receptor $(\mathrm{Ob}-\mathrm{R})$ messenger ribonucleic acid expression in rat testis. Biology of Reproduction 64 634-643.

Tsai-Morris CH, Khanum A, Tang P-Z \& Dufau ML 1999 The rat 17ß-hydroxysteroid dehydrogenase type III: molecular cloning and gonadotropin regulation. Endocrinology 140 3534-3542.

White DW \& Tartaglia LA 1999 Evidence for ligand-independent homo-oligomerization of leptin receptor (OB-R) isoforms: A proposed mechanism permitting productive long-form signalling in the presence of excess short-form expression. Journal of Cellular Biochemistry 73 278-288.

White DW, Kuropatwinski KK, Devos R, Baumann H \& Tartaglia LA 1997 Leptin receptor (OB-R) signaling. Cytoplasmic domain mutational analysis and evidence for receptor homo-oligomerization. Journal of Biological Chemistry 272 4065-4071.

Zachow RJ, Weitsman SR \& Magoffin DA 1999 Leptin impairs the synergistic stimulation by transforming growth factor- $\beta$ of folliclestimulating hormone-dependent aromatase activity and messenger ribonucleic acid expression in rat ovarian granulosa cells. Biology of Reproduction 61 1104-1109.

Zamorano PL, Mahesh VB, de Sevilla LM, Chorich LP, Bhat GK \& Brann DW 1997 Expression and localization of the leptin receptor in endocrine and neuroendocrine tissues of the rat.

Neuroendocrinology 65 223-228.

Received 18 December 2000

Accepted 12 April 2001 